\title{
Mechanochemical Synthesis of (Co,Cu,Mg,Ni,Zn)O High-Entropy Oxide and Its Physicochemical Properties
}

\author{
MATEUSZ BALCERZAK, ${ }^{1}$ KENICHI KAWAMURA, ${ }^{2}$ RAFAŁ BOBROWSKI, ${ }^{3}$ \\ PAWE $Ł$ RUTKOWSKI ${ }^{3}$ and TOMASZ BRYLEWSKI ${ }^{3,4}$ \\ 1.-Institute of Materials Science and Engineering, Poznan University of Technology, Jana Pawla \\ II No 24, 61-138 Poznan, Poland. 2.-Department of Metallurgy and Ceramics Sciences, Graduate \\ School of Science and Engineering, Tokyo Institute of Technology, 2-12-1 Ookayama, Meguro-ku, \\ Tokyo 152-8552, Japan. 3.-Faculty of Materials Science and Ceramics, AGH University of \\ Science and Technology, Al. Mickiewicza 30, 30-059 Kraków, Poland. 4.-e-mail: \\ brylew@agh.edu.pl
}

The study describes the physicochemical properties of transition metal (Co,$\mathrm{Cu}, \mathrm{Mg}, \mathrm{Ni}, \mathrm{Zn}) \mathrm{O}$ high-entropy oxide prepared using mechanochemical synthesis (MS) followed by thermal treatment, as well as the structural evolutions in the powder with milling time. The microstructure and electrical properties of the materials were studied using x-ray diffraction, scanning electron microscopy-energy dispersive spectroscopy and electrochemical impedance spectroscopy. The powders obtained after $30 \mathrm{~h}$ and $100 \mathrm{~h}$ of MS contained a mixture of two phases with a rock salt structure and, in addition, about 11 wt.\% of $\mathrm{Co}_{3} \mathrm{O}_{4}$. Sintering these materials for $10 \mathrm{~h}$ in air at $1273 \mathrm{~K}$ led to the formation of a single-phase, solid solution with a rock salt structure. The developed sinters exhibited a fine-crystalline structure of grains and a uniform distribution of elements. The highest electrical conductivity was measured at $1148 \mathrm{~K}$, and it was equal to $8.03 \times 10^{-2} \mathrm{~S} \mathrm{~cm}^{-1}$.

Key words: Milling, electrical conductivity, transition metal oxides, high-entropy oxides

\section{INTRODUCTION}

Materials stabilized via a high-configuration entropy of the system are a very interesting example of a materials engineering concept that originated with high-entropy alloys (HEAs), also known as multi-principal element alloys. Such materials exhibit very desirable strength properties at low densities $^{1,2}$ as well as advantageous magnetic, ${ }^{3}$ electrical $^{4}$ and chemical ${ }^{5,6}$ properties. Because of the increased interest in the use of energy from renewable sources and hydrogen as an energy carrier, alloys such as $\mathrm{CoFeMnTi} \mathrm{V}_{x} \mathrm{~V}_{z}$ may become a new generation of hydrogen storage materials. ${ }^{7}$

With the development of this concept, which involves the stabilization of a solid solution via a

(Received March 1, 2019; accepted July 31, 2019

published online August 14, 2019) high-configuration entropy maintained by at least five constituents randomly distributed across the crystalline structure at an equimolar ratio, three new systems of this type were designed, namely high-entropy alloy nitrides (HEANs) ${ }^{8}$ high-entropy metal diborides (HEBs), ${ }^{9}$ and high-entropy carbides as a novel class of multicomponent ceramics. ${ }^{10}$

Since the successful synthesis of an equimolar, $\mathrm{Fm}-3 \mathrm{~m}$ single-phase ( $\mathrm{Co}, \mathrm{Cu}, \mathrm{Mg}, \mathrm{Ni}, \mathrm{Zn}) \mathrm{O}$ solid solution by Rost et al. ${ }^{11}$ in 2015 , the scientific community has taken a growing interest in the new group of ceramic materials referred to as high-entropy oxides (HEOx). The stabilization of ceramics via a high-configuration entropy may yield a number of unique properties as a result of the synergistic interactions between various pairs of ions. This is the main difference in relation to conventional materials, in which properties are determined entirely by one or two main components. 
Bérardan et al. ${ }^{12,13}$ combined such stabilization with doping by means of different alkali ions $(\mathrm{Li}$, $\mathrm{Na}$ ) and obtained modified HEOx materials that exhibited enormous dielectric constants. Moreover, the $(\mathrm{Co}, \mathrm{Cu}, \mathrm{Mg}, \mathrm{Ni}, \mathrm{Zn})_{0.7} \mathrm{Li}_{0.3} \mathrm{O}$ oxide they synthesized was characterized by high ionic conductivity at room temperature, making it a promising material for the development of LiPON cells to be applied in mobile devices. The results of this investigation and the subsequent studies conducted by Rak et al. ${ }^{14}$ Djenadic et al., ${ }^{15}$ Bérardan et al. ${ }^{16}$ and Rost et al. ${ }^{17}$ in order to better understand the structural and physicochemical properties of such materials provided the inspiration for the development of new classes of HEOx ceramics-one with a perovskite structure, which was synthesized by a team led by Luo, ${ }^{18}$ and another with a $(\mathrm{Co}, \mathrm{Cr}, \mathrm{Fe}, \mathrm{Mn}, \mathrm{Ni})_{3} \mathrm{O}_{4}$ spinel structure, synthesized by Danielewski's group. ${ }^{19}$

Current research on transition metal high-entropy oxides (TM-HEOs) indicates that it is possible to synthesize these materials by means of techniques other than the solid-state reaction. ${ }^{11,12,18,19}$ For example, numerous studies conducted for different ceramic systems have determined that wet chemistry methods, which include the sol-gel method, the citrate process, and co-precipitation, among others, are far superior to solid-state reaction methods, since they allow the degree of powder granularity and the purity of the system to be controlled, ensure a narrow particle size distribution, and-in the case of multi-component systems-their high homogeneity. Furthermore, they enable lower sintering temperatures and shorter thermal treatment times.

Sarkar et al. ${ }^{20}$ applied nebulized spray pyrolysis (NSP), flame spray pyrolysis (FSP) and reverse coprecipitation (RCP) techniques to synthesize (Co,Mg,Ni,Zn)O and (Co, $\mathrm{Cu}, \mathrm{Mg}, \mathrm{Ni}, \mathrm{Zn}) \mathrm{O}$, successfully obtaining nanomaterials stabilized via highconfiguration entropy. According to these authors, the application of the NSP method allows the singlephase, rock salt $(\mathrm{Co}, \mathrm{Cu}, \mathrm{Mg}, \mathrm{Ni}, \mathrm{Zn}) \mathrm{O}$ to be directly stabilized at a lower temperature, without the thermal treatment stage that is required in the case of FSP and RCP.

In view of the above-mentioned results, it seemed worth undertaking the preparation of a TM-HEOs material with the composition of $(\mathrm{Co}, \mathrm{Cu}, \mathrm{Mg}$,$\mathrm{Ni}, \mathrm{Zn}) \mathrm{O}$ via mechanochemical synthesis (MS). This type of processing is a special method that involves the mechanical activation of solid-state chemical reactions via displacement during ball milling; it has been extensively studied in recent years and was used to synthesize metallic, oxide and sulfide nanoparticles. ${ }^{21-24}$ The main advantage of this method is that the process is carried out in the solid state and makes it is easier to control the overall particle size distribution. If suitable conditions, such as milling parameters, ball-to-powder ratio $(\mathrm{BPR})$ and the stoichiometric ratio of the starting materials, are selected, mechanochemical processing can be used to synthesize nanocrystalline powders with a precise chemical composition and homogeneous microstructure. An attempt to apply the mechanochemical method for the preparation of the $(\mathrm{Co}, \mathrm{Cu}, \mathrm{Mg}, \mathrm{Ni}, \mathrm{Zn}) \mathrm{O}$ sample was made, since this would have allowed the $\mathrm{Co}_{3} \mathrm{O}_{4}$ starting material to be used as a precursor of $\mathrm{Co} \mathrm{Co}_{3} \mathrm{O}_{4}$ is inexpensive and more readily available than $\mathrm{CoO}$ in the rock salt form, i.e. the material usually used for this purpose.

The primary goal of this study was to synthesize a fine, single-phase $(\mathrm{Co}, \mathrm{Cu}, \mathrm{Mg}, \mathrm{Ni}, \mathrm{Zn}) \mathrm{O}$ solid solution bulk sample using MS technique by optimizing the milling process and the thermal treatment conditions. The structure and morphology of the powders and the bulk sample were studied by means of x-ray diffraction (XRD), scanning electron microscopy (SEM), whereas the electrical conductivity of the bulk sample was investigated via electrochemical impedance spectroscopy (EIS). The structural evolutions of the powder with milling time were also evaluated.

\section{EXPERIMENTAL PROCEDURE}

\section{Chemicals}

The following commercial binary oxide powders were used as starting materials: magnesium oxide (Sigma-Aldrich, 99.99\%, - 325 mesh), cobalt(II,III) oxide (Fluka Chemie, $>71.0$ wt. $\%$ of $\mathrm{Co},<10 \mu \mathrm{m}$ ), nickel(II) oxide (Sigma-Aldrich, 99\%, - 325 mesh), copper(II) oxide (Sigma-Aldrich, 99.99\%, - 200 mesh) and zinc oxide (Sigma-Aldrich, $\geq 99 \%,-200$ mesh).

As per the criteria for the choice of the cations for the synthesis of the TM-HEOs material, suggested by Rost et al., ${ }^{11}$ Table I gives an overview of the crystal structure, space group, oxidation state, coordination number and corresponding cationic radius of each of the individual binary oxides used as starting materials in the present study. ${ }^{25,26}$

\section{Preparation of Materials}

The starting oxide powders were weighed in equimolar proportions and mixed by means of the MS technique. A shaker-type ball mill (SPEX 8000 Mixer/Mill) was used. The ball-to-powder weight ratio (BPR) was $6: 1$ during the first $30 \mathrm{~h}$ of synthesis and 11:1 during the subsequent $70 \mathrm{~h}$ of synthesis. The rationale for modifying the BPR during synthesis is given in a later section of this work. The applied balls and mixing vial were both made of stainless steel. The entire MS process lasted $100 \mathrm{~h}$ and was carried out in air. Two types of samples were studied-powders synthesized for $30 \mathrm{~h}$, and powders synthesized for $100 \mathrm{~h}$. The first synthesis stage was briefly interrupted at certain time intervals ( $5 \mathrm{~min}, 1 \mathrm{~h}, 4 \mathrm{~h}, 8 \mathrm{~h}, 15 \mathrm{~h}, 30 \mathrm{~h}$ and $100 \mathrm{~h}$ ) in 
Table I. Crystal structure, space group, oxidation state, co-ordination number (CN) and corresponding cationic radius $\left(r_{c}\right)$ of binary oxides used as starting materials

\begin{tabular}{|c|c|c|c|c|c|}
\hline Oxide & Structure & $r_{c}(\AA)^{25}$ & Space group (number) ${ }^{26}$ & Oxidation state & $\mathbf{C N}$ \\
\hline $\mathrm{Co}_{3} \mathrm{O}_{4}$ & Spinel & $\begin{array}{l}0.58 \\
0.55\end{array}$ & $F d \overline{3} m(227)$ & $\begin{array}{c}2+(\text { high-spin state }) \\
3+(\text { low-spin state })\end{array}$ & $\begin{array}{l}\text { IV } \\
\text { VI }\end{array}$ \\
\hline $\mathrm{CuO}$ & Tenorite & 0.73 & $C 12 / c 1(15)$ & $2+$ & VI \\
\hline $\mathrm{MgO}$ & Rock salt & 0.72 & $F m \overline{3} m(225)$ & $2+$ & VI \\
\hline $\mathrm{NiO}$ & Rock salt & 0.69 & $F m \overline{3} m(225)$ & $2+$ & VI \\
\hline $\mathrm{ZnO}$ & Wurztite & 0.60 & $\mathrm{~Pb}_{3} \mathrm{mc}(186)$ & $2+$ & IV \\
\hline $\mathrm{ZnO}$ & Rock salt & 0.74 & $F m \overline{3} m(225)$ & $2+$ & VI \\
\hline
\end{tabular}

Source of data indicated in column heading, where appropriate.

order to study the structural evolutions occurring in the powders.

To prepare bulk samples with a diameter of $8 \mathrm{~mm}$ and a height of about $2 \mathrm{~mm}$, the powders were pressed under $200 \mathrm{MPa}$, and the obtained green bodies were then free-sintered for $10 \mathrm{~h}$ in static air at $1273 \mathrm{~K}$, with a heating rate of $5 \mathrm{~K} \mathrm{~min}^{-1}$. After heat treatment, the samples were promptly removed and air-quenched. The obtained sinters are subsequently referred to as HEOX-30 h MS and HEOX-100 h MS.

\section{Methodology}

A PANalytical Empyrean powder diffractometer $(\mathrm{Cu}$ $\mathrm{K} \alpha \alpha_{1}$ radiation, $\lambda=1.5405952 \AA$ ) was used to investigate the structure of the investigated powders. XRD measurements were performed at room temperature. The voltage and anode current were $45 \mathrm{kV}$ and $40 \mathrm{~mA}$, respectively. The XRD profiles were refined with the Rietveld method using the Maud software.

Another diffractometer, namely the PANalytical X'Pert, was used for the phase analysis of the sintered pellets, which involved heating them to $1273 \mathrm{~K}$, and then cooling them to room temperature. An MRI temperature camera (MRI TC) with a $\mathrm{Pt}$ strip heater was used for this purpose. Measurements were performed in a standard configuration (step: $0.008^{\circ}$, time per step: $80 \mathrm{~s}$, X'Celerator strip detector). Qualitative phase analyses were conducted using the HighScore Plus software (PANalytical) coupled with the X'Pert diffractometer and the PCPDFWIN v.2.3 standard data set.

The morphology of agglomerates and chemical composition of the obtained MS powders were determined via SEM and energy dispersive spectroscopy (EDS) performed by means of the Tescan VEGA TS5135 digital imaging microscope. A fieldemission scanning electron microscope (JEOL JSM7000F) coupled with EDAX's Octane Silicon Drift Detector (SDD) for EDS was used to examine the morphology and chemical composition of the sinters.

The relative density of the investigated bulk samples was determined by dividing the apparent density obtained experimentally (via the hydrostatic weighing of sinters in distilled water) by the theoretical density calculated based on crystallographic data. The total porosities were computed from the following equation:

$$
P_{c}=\left(1-\frac{d_{\mathrm{a}}}{d_{\mathrm{XRD}}}\right) \times 100 \%
$$

where: $P_{c}$-total porosity $(\%), d_{\mathrm{a}}$-apparent density $\left(\mathrm{g} \mathrm{cm}^{-3}\right), d_{\mathrm{XRD}}$ - theoretical density $\left(\mathrm{g} \mathrm{cm}^{-3}\right)$.

The electrical resistance of the studied samples was measured using a Hioki LCR meter in the AC mode, an amplitude of $0.2 \mathrm{~V}$, and with a frequency ranging from $0.1 \mathrm{~Hz}$ to $1 \mathrm{~Hz}$. The obtained values were assumed as the DC resistance values (no imaginary impedance component at this frequency). Electrodes were prepared by covering sinter samples with Pt paste (Heraeus) and heated to $1273 \mathrm{~K}$ at a rate of $5 \mathrm{~K} \mathrm{~min}^{-1}$ in laboratory air. Samples were then placed in-between spring loaded $\mathrm{Pt}$ meshes. The temperature dependence of electrical resistance was measured between $478 \mathrm{~K}$ and $1148 \mathrm{~K}$ at $25 \mathrm{~K}$ intervals during cooling; at each measurement temperature, data was collected after the temperature had been stable for $30 \mathrm{~min}$.

The electrical conductivity of the sinters was determined based on the obtained electrical resistance values, their dimensions, and the following dependence:

$$
\sigma=\frac{L}{S \cdot R}
$$

where $R$ represents electrical resistance $(\Omega), S$ represents the cross-sectional surface area $\left(\mathrm{cm}^{2}\right), L$ represents sample thickness $(\mathrm{cm})$. The sample preparation and the apparatus and methods used to measure electrical resistance are described in Ref. 27.

\section{RESULTS AND DISCUSSION}

\section{Physicochemical Characteristics of the Studied Powders}

The objective of the synthesis was to obtain a single-phase solid solution with a rock salt 
structure, which crystallizes in the $F m-3 m$ space group. This space group is also observed in the case of $\mathrm{MgO}$ and $\mathrm{NiO}$ (Table I).

Figure 1 presents XRD patterns recorded for a mixture of $\mathrm{MgO}, \mathrm{Co}_{3} \mathrm{O}_{4}, \mathrm{NiO}, \mathrm{CuO}$ and $\mathrm{ZnO}$ powders mechanochemically synthesized in air over $5 \mathrm{~min}$ and $1 \mathrm{~h}, 4 \mathrm{~h}, 8 \mathrm{~h}, 15 \mathrm{~h}, 30 \mathrm{~h}$ or $100 \mathrm{~h}$. It is evident that the $\mathrm{ZnO}$ and $\mathrm{CuO}$ diffraction peaks, which were initially relatively sharp, became broader and less pronounced for longer milling times. After $15 \mathrm{~h}$ of MS, the peaks originating from these phases were no longer visible. In this case, they co-formed the $\mathrm{NiO}$ - and $\mathrm{MgO}$-based $\mathrm{NaCl}$-type solid solutions or the $\mathrm{Co}_{3} \mathrm{O}_{4}$-based solid solution (structure crystallized in an Fd3m space group, Table I). Moreover, a reflection attributed to the $\mathrm{NaCl}$ structure was visible after $30 \mathrm{~h}$ of MS. Due to the MS process, both solid solutions ( $\mathrm{NiO}$ - and $\mathrm{MgO}$-based) became homogenized. Unfortunately, $\mathrm{Co}_{3} \mathrm{O}_{4}$ peaks were still visible after $30 \mathrm{~h}$ of MS. The Co oxide did not react with the remaining oxides, perhaps due to the insufficient energy of the synthesis. To verify this,

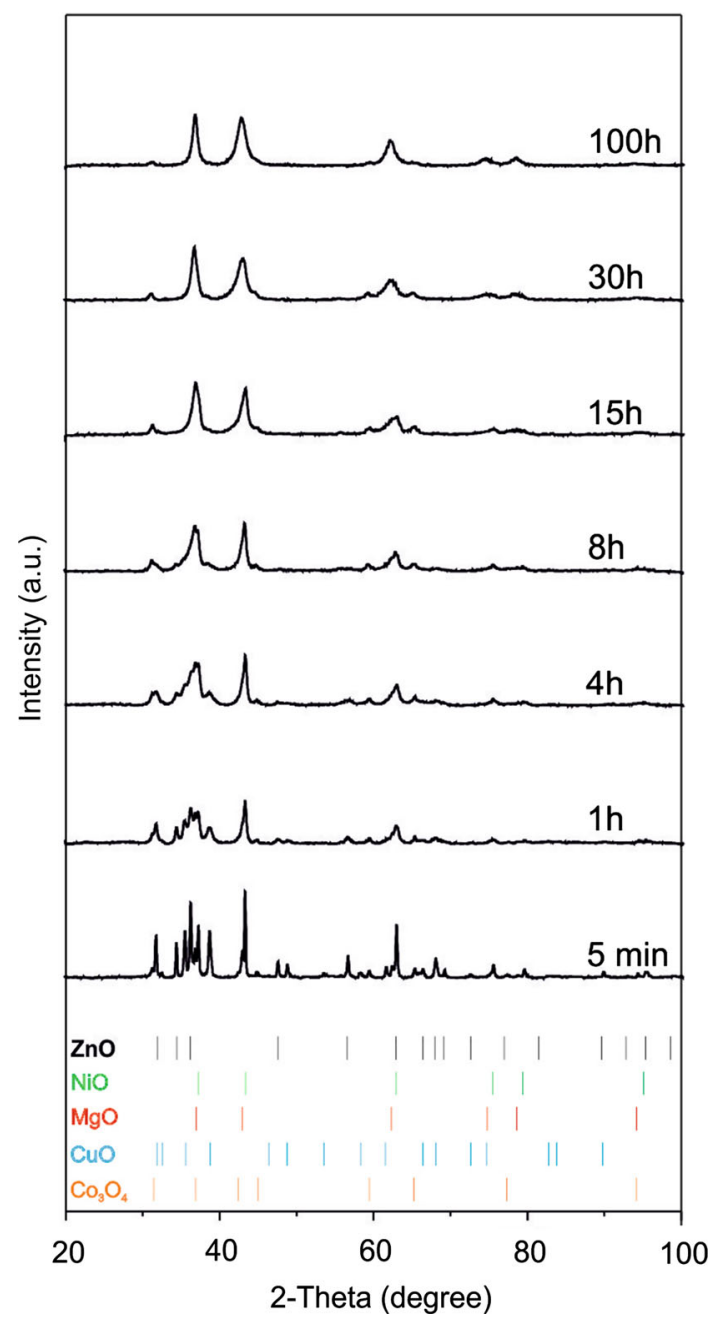

Fig. 1. XRD patterns of a mixture of $\mathrm{MgO}, \mathrm{Co}_{3} \mathrm{O}_{4}, \mathrm{NiO}, \mathrm{CuO}$ and $\mathrm{ZnO}$ powders mechanochemically synthesized over different times. the BPR was increased from $6: 1$ to $11: 1$ and the material underwent another $70 \mathrm{~h}$ of MS. Despite this, $\mathrm{Co}_{3} \mathrm{O}_{4}$ failed to dissolve in the solid solution with the rocksalt structure; the reason for this was the high stability of this phase in air at ambient temperature, as indicated by the phase diagram for the $\mathrm{Co}_{3} \mathrm{O}_{4}-\mathrm{CoO}$ system. ${ }^{28}$

The results of qualitative phase analyses performed based on the Rietveld profile refinement method indicate that the mechanochemical synthesis of the powders obtained after $30 \mathrm{~h}$ or $100 \mathrm{~h}$ of milling yielded a mixture of two phases with a rock salt structure and a phase of $\mathrm{Co}_{3} \mathrm{O}_{4}$-based solid solution. This can be seen by examining the XRD pattern recorded for the powder obtained after $30 \mathrm{~h}$ of MS, shown in Fig. 2; in addition to the experimental curve, this figure also includes a curve plotted based on the performed Rietveld analysis and its constituents related to the two afore-mentioned phases.

Table II lists the relative mass contribution of phases formed in the studied powders after milling for either $30 \mathrm{~h}$ or $100 \mathrm{~h}$; the actual compositions of the NaCl-type solid solution, calculated based on the corresponding data, are also listed. These data show that the main phase with a rock salt structure in either of the afore-mentioned powders is a fourcomponent compound with the composition of $\mathrm{Cu}_{0.25} \mathrm{Mg}_{0.25} \mathrm{Ni}_{0.25} \mathrm{Zn}_{0.25} \mathrm{O}$ and a mass contribution of ca. $68 \mathrm{wt} . \%$. This is because a significant fraction of the $\mathrm{Co}_{3} \mathrm{O}_{4}$ spinel (11\% of the total powder mass) had not incorporated into the NaCl-type solid solution structure. In fact, only a small amount of the spinel formed the $\mathrm{Co}_{0.2} \mathrm{Cu}_{0.2} \mathrm{Mg}_{0.2} \mathrm{Ni}_{0.2} \mathrm{Zn}_{0.2} \mathrm{O}$ compound with four other components; the mass contribution of this compound was estimated to be ca. $32 \%$. It should be noted that prolonging the milling time by $70 \mathrm{~h}$ did not result in a significant increase in the contribution of cobalt in the fivecomponent phase with a rock salt structure

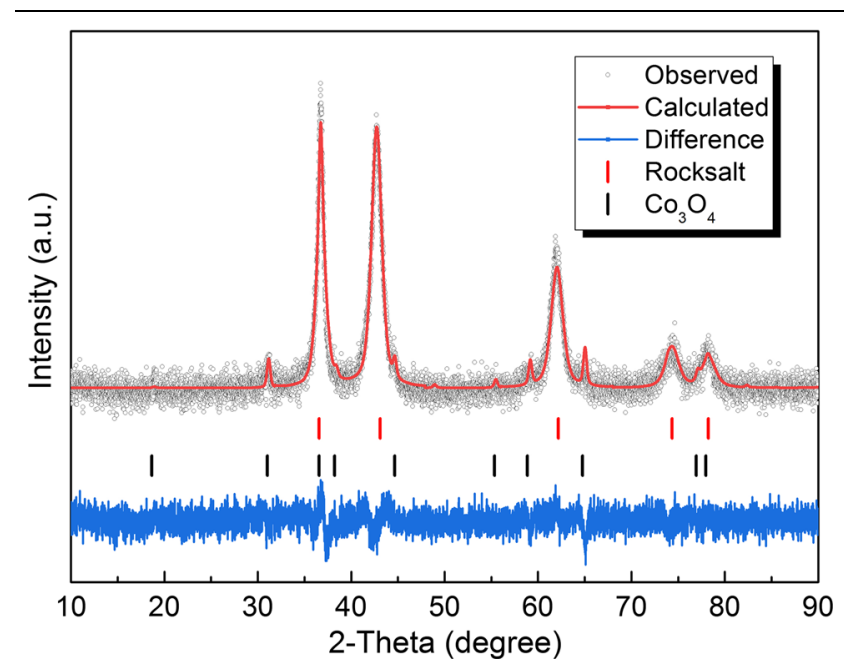

Fig. 2. XRD pattern recorded for a powder obtained after $30 \mathrm{~h}$ of MS and the corresponding curve plotted based on Rietveld analysis. 
Table II. Relative mass contribution of phases identified in powders after $30 \mathrm{~h}$ and $100 \mathrm{~h}$ of $\mathrm{MS}$ and the corresponding actual NaCl-type solid solution compositions

\begin{tabular}{|c|c|c|c|}
\hline \multirow[b]{2}{*}{ Powder } & \multicolumn{2}{|c|}{ Mass contribution (\%) } & \multirow{2}{*}{$\begin{array}{l}\text { Actual composition of NaCl-type solid solution } \\
\text { (mass fraction of individual oxides) }\end{array}$} \\
\hline & NaCl-type solid solution & $\mathrm{Co}_{3} \mathrm{O}_{4}$ & \\
\hline $30 \mathrm{~h} \mathrm{MS}$ & 89.0 & 11.0 & $\begin{array}{c}\mathrm{Co}_{0.2} \mathrm{Cu}_{0.2} \mathrm{Mg}_{0.2} \mathrm{Ni}_{0.2} \mathrm{Zn}_{0.2} \mathrm{O}(31.5 \%) \\
\mathrm{Cu}_{0.25} \mathrm{Mg}_{0.25} \mathrm{Ni}_{0.25} \mathrm{Zn}_{0.25} \mathrm{O}(68.5 \%)\end{array}$ \\
\hline $100 \mathrm{~h} \mathrm{MS}$ & 89.4 & 10.6 & $\begin{array}{c}\mathrm{Co}_{0.2} \mathrm{Cu}_{0.2} \mathrm{Mg}_{0.2} \mathrm{Ni}_{0.2} \mathrm{Zn}_{0.2} \mathrm{O}(31.7 \%) \\
\mathrm{Cu}_{0.25} \mathrm{Mg}_{0.25} \mathrm{Ni}_{0.25} \mathrm{Zn}_{0.25} \mathrm{O}(68.3 \%)\end{array}$ \\
\hline
\end{tabular}
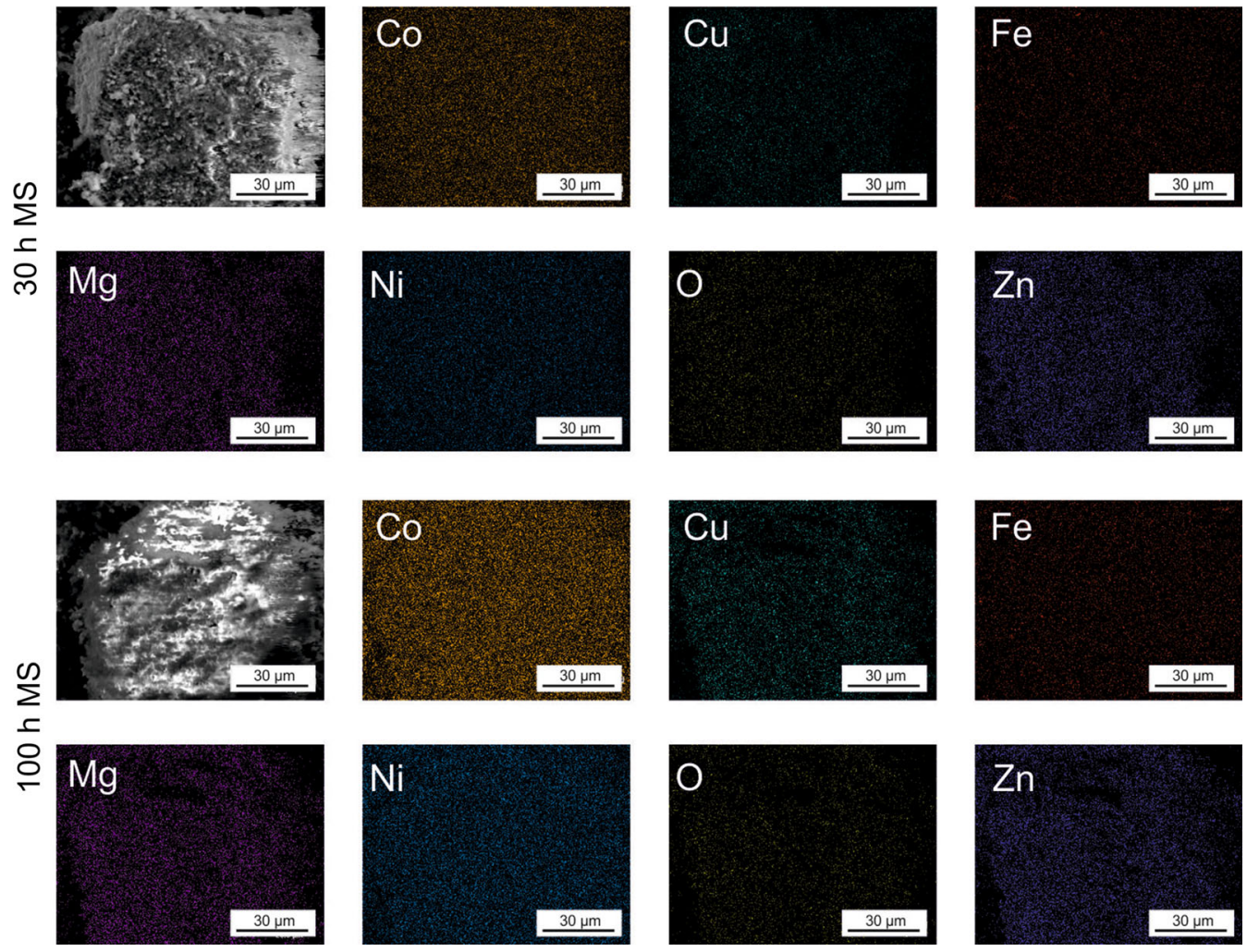

Fig. 3. SEM micrographs of the powders obtained after $30 \mathrm{~h}$ and $100 \mathrm{~h}$ of MS and corresponding EDS element maps of Co K $\alpha_{1}$, Cu K $\alpha_{1}$, Fe K $\alpha_{1}$, $\mathrm{Mg} \mathrm{K} \alpha_{1}, \mathrm{Ni} \mathrm{K} \alpha_{1}, \mathrm{O} \mathrm{K} \alpha_{1}$ and $\mathrm{Zn} \mathrm{K} \alpha_{1}$.

(Table II), but it merely made the spinel phase finer, as indicated by the broadening of reflections such as the one originating from the (511) family of planes for the $\mathrm{Co}_{3} \mathrm{O}_{4}$ phase.

Figure 3 shows the SEM micrographs of the obtained powders after $30 \mathrm{~h}$ and $100 \mathrm{~h}$ of MS and the EDS element maps corresponding to the areas shown in the micrographs. Regardless of the time of synthesis, $\mathrm{Mg}, \mathrm{Cu}, \mathrm{Ni}, \mathrm{Co}, \mathrm{Zn}$ and $\mathrm{O}$ elements were uniformly distributed across virtually the entire area of the material. In addition to the elements present in the starting materials, $\mathrm{Fe}$ atoms were found during EDS measurements. The mass fraction of this element ranged from $1.5 \mathrm{wt} . \%$ to 1.9 wt.\%. This iron contamination originated from the stainless steel of the mixing vial and the milling balls.

SEM micrographs of the powders obtained after $30 \mathrm{~h}$ and $100 \mathrm{~h}$ of MS are shown in Fig. 4. The morphology of the two materials was similar-small grains forming agglomerates with a size of $0.1-$ $5 \mu \mathrm{m}$.

\section{Physicochemical Properties of the Obtained Sinters}

XRD phase analyses were performed in situ at room temperature and over the temperature range of $373-1273 \mathrm{~K}$ during heating and cooling for HEOX-30 $\mathrm{h}$ MS and HEOX-100 $\mathrm{h}$ MS sinters obtained by thermally treating $(10 \mathrm{~h}$, air, $1273 \mathrm{~K})$ 

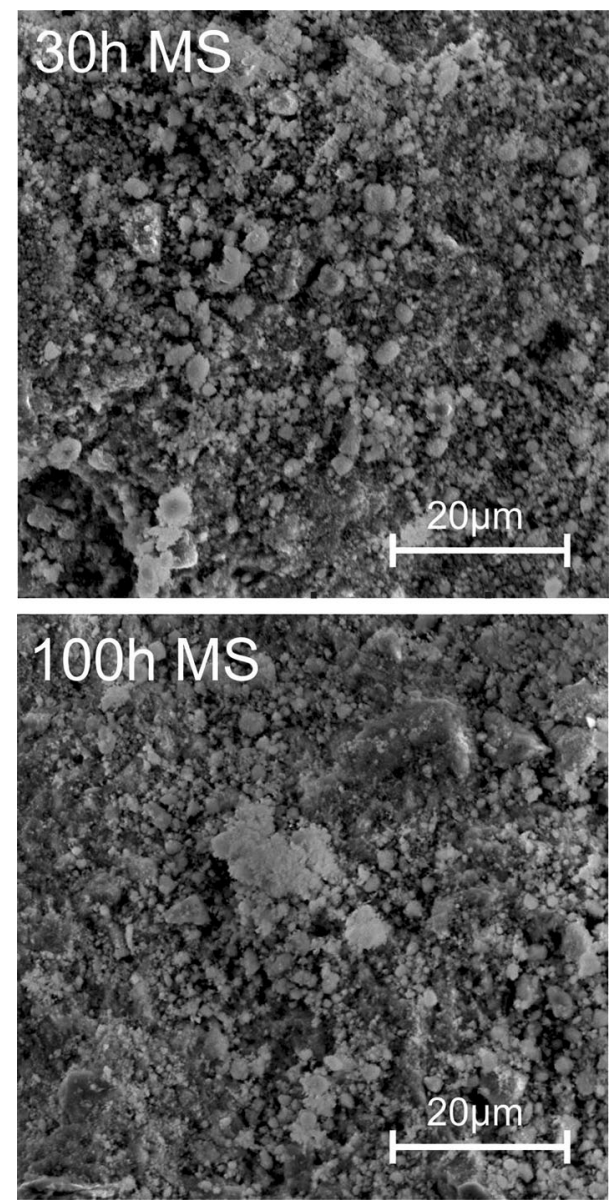

Fig. 4. SEM micrographs of the powders obtained after $30 \mathrm{~h}$ and $100 \mathrm{~h}$ of MS.

green bodies prepared from powders after $30 \mathrm{~h}$ and $100 \mathrm{~h}$ of MS. These analyses showed that the structure of the NaCl-type solid solution in the studied sinters did not change with temperature; instead, they retained their $F m-3 m$ rock salt form, indicating $(\mathrm{Co}, \mathrm{Cu}, \mathrm{Mg}, \mathrm{Ni}, \mathrm{Zn}) \mathrm{O}$ stoichiometry. Moreover, reflections originating from the $\mathrm{Co}_{3} \mathrm{O}_{4}$ phase were no longer visible. The lattice parameters of the HEOX-30 $\mathrm{h}$ MS and HEOX-100 $\mathrm{h}$ MS sinters at room temperature were determined to be 4.23842 $( \pm 0.0005)$ and $4.23624( \pm 0.0012) \AA$, respectively. These results are consistent with those reported by other authors. ${ }^{11,20}$

Figure 5 shows a number of XRD patterns that were recorded for the HEOX-30 h MS sinter while it was being heated in the temperature range of RT$1273 \mathrm{~K}$. In addition to the reflections attributed to the rock salt phase, some low-intensity reflections can also be seen; the latter originated from the alundum plate on which the sample had been placed during high-temperature x-ray measurements.

Figure 6 presents the temperature dependence of lattice parameter $a$ of the HEOX-30 h MS sinter observed while this material was being heated and cooled over the range of RT- $1273 \mathrm{~K}$. This dependence is linear for the cooling process. On the other

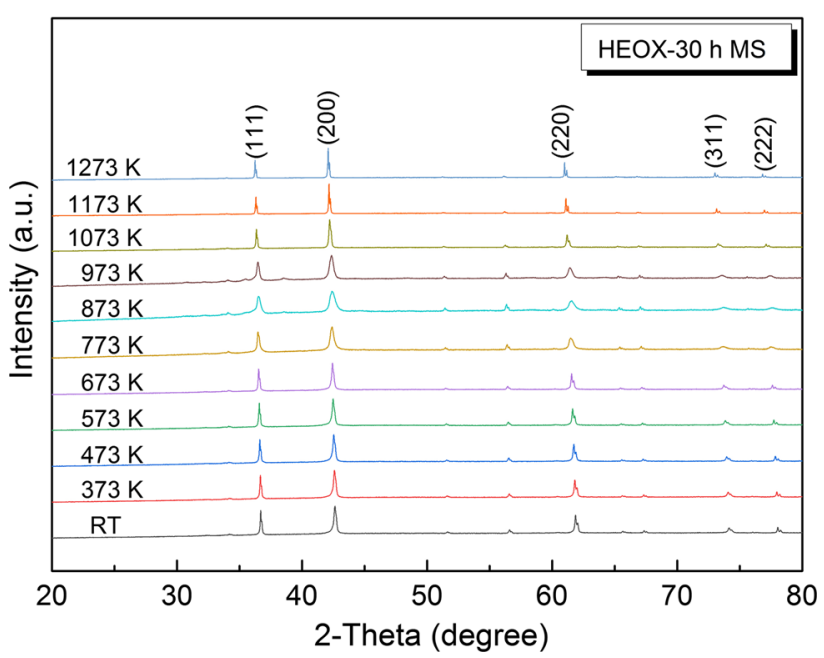

Fig. 5. RT and high-temperature $\mathrm{x}$-ray diffraction patterns recorded for the HEOX-30 h MS sinter while this material was being heated from room temperature and up to $1273 \mathrm{~K}$.

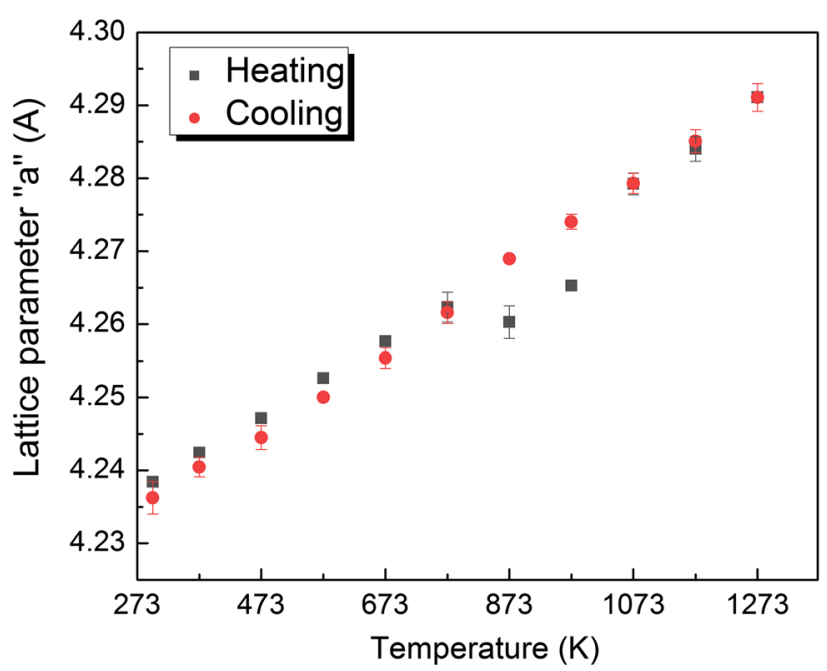

Fig. 6. Lattice parameter $a$ as a function of temperature in the HEOX-30 h MS sinter while this material was being heated and cooled over the range of RT-1273 K.

hand, when heating the sample, an anomaly in the plot representing the values of this lattice parameter can be observed in the temperature range between $773 \mathrm{~K}$ and $1073 \mathrm{~K}$. This is associated with the phase reversal temperature, a phenomenon first observed by the authors of paper. ${ }^{11}$ The thermal expansion coefficient of the HEOX-30 h MS sinter, determined based on the linear plot representing parameter $a$ (corresponding only to cooling for the above-mentioned reasons), is equal to $13.4 \times 10^{-6}$ $\left(\mathrm{K}^{-1}\right)$.

As an example, Fig. 7 shows the SEM micrograph of a fracture cross-section of the HEOX-30 h MS sinter. The presented sample was compact and featured a certain number of pores between the grains. The micrograph indicates that its grains had a fine-crystalline structure. The size of these grains ranged from $1 \mu \mathrm{m}$ to $5 \mu \mathrm{m}$. 
To further confirm the uniformity of the HEOX$30 \mathrm{~h}$ MS sinter, EDS mapping was performed. As can be seen from Fig. 8, no tendencies to segregate or form other phases were found.

There is a certain feature that is worth noting. Due to the presence of pores with varying size in the sample, the quantities of $\mathrm{Co}, \mathrm{Cu}, \mathrm{Ni}, \mathrm{Zn}, \mathrm{Mg}$ and $\mathrm{O}$
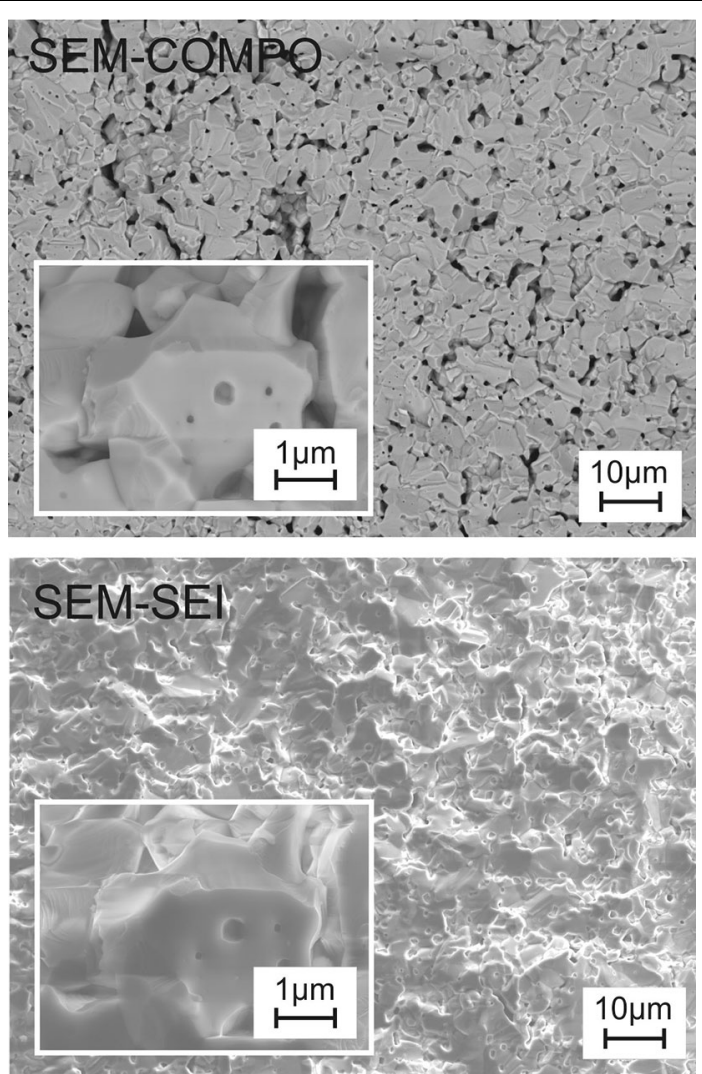

Fig. 7. SEM-COMPO and SEM-SEI micrographs of fracture crosssections of HEOX-30 h MS sinter after $10 \mathrm{~h}$ of sintering in air at $1273 \mathrm{~K}$. seen in their distribution maps (Fig. 8) differ significantly, even though these elements were present in equimolar fractions. This stemmed from the differences in the energy of K-alpha emission lines observed for these elements. ${ }^{29}$ The energy of $\mathrm{Mg}$ and $\mathrm{O}\left(K_{\alpha(\mathrm{Mg})}=1.254 \mathrm{keV} ; K_{\alpha(\mathrm{O})}=0.523 \mathrm{keV}\right)$ is much lower than the energy of the remaining elements $\left(K_{\alpha(\mathrm{Co})}=6.929 \mathrm{keV} ; \quad K_{\alpha(\mathrm{Cu})}=8.046 \mathrm{keV} ; \quad K_{\alpha(\mathrm{Ni})}=\right.$ $\left.7.477 \mathrm{keV} ; K_{\alpha(\mathrm{Zn})}=8.637 \mathrm{keV}\right)$, which is why the $K$-alpha emission of the former is unable to travel outside the majority of the pores. In the case, of $\mathrm{Co}$, $\mathrm{Cu}, \mathrm{Ni}$ and $\mathrm{Zn}$, the situation is different. Their $K$ alpha emission escapes most pores in the sample-it can only be contained in the pores with the largest size.

Table III lists the values of total porosity as well as the apparent density measured for the HEOX$30 \mathrm{~h}$ MS and HEOX-100 h MS sinters after $10 \mathrm{~h}$ of sintering in air at $1273 \mathrm{~K}$ and the corresponding values of relative densities calculated using theoretical density established based on crystallographic data.

The presented data demonstrate that the HEOX$100 \mathrm{~h}$ MS sinter exhibits slightly higher density than the sample prepared from the powder that had undergone only $30 \mathrm{~h}$ of milling (HEOX-30 h MS). The porosity does not exceed $12 \%$ for either type of sample.

Since the porosities and phase compositions of the two investigated types of sinter samples were very similar, only the HEOX-30 h MS sinter obtained in the presented study was evaluated in terms of its electrical conductivity.

Figure 9 shows the temperature dependence of electrical conductivity $\left(\sigma_{\mathrm{m}}\right)$ for this sinter in an Arrhenius plot. The plot clearly shows that the electrical conductivity of the sample increases together with temperature, which is typical of a thermally activated process.
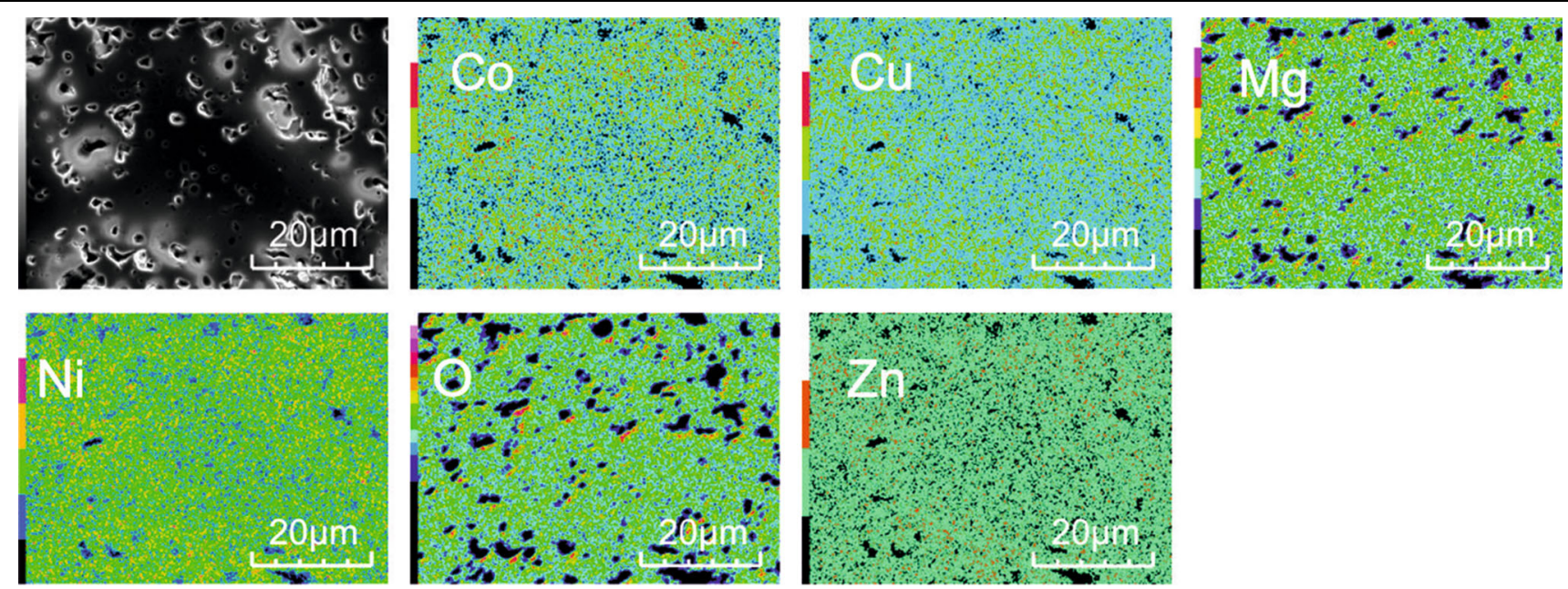

Fig. 8. SEM micrograph of HEOX-30 h MS sinter after $10 \mathrm{~h}$ of sintering in air at $1273 \mathrm{~K}$ and EDS element maps of Co K $\alpha_{1}$, Cu K $\alpha_{1}$, Mg K $\alpha_{1}$, Ni $\mathrm{K} \alpha_{1}, \mathrm{O} \mathrm{K} \alpha_{1}$ and $\mathrm{Zn} \mathrm{K} \alpha_{1}$. 
Table III. Determined porosity and theoretical and relative density of the studied sinters after $10 \mathrm{~h}$ of sintering in air at $1273 \mathrm{~K}$

\begin{tabular}{|c|c|c|c|c|}
\hline Sinter & $\begin{array}{l}\text { Theoretical density } \\
\qquad\left(\mathrm{g} \mathrm{cm}^{-3}\right)\end{array}$ & $\begin{array}{c}\text { Apparent density } \\
\left(\mathrm{g} \mathrm{cm}^{-3}\right)\end{array}$ & $\begin{array}{c}\text { Relative } \\
\text { density }(\%)\end{array}$ & $\begin{array}{c}\text { Total } \\
\text { porosity }(\%)\end{array}$ \\
\hline HEOX-30 h MS & 6.002 & $5.29 \pm 0.13$ & 88.1 & 11.9 \\
\hline HEOX-100 h MS & 6.037 & $5.41 \pm 0.08$ & 89.6 & 10.4 \\
\hline
\end{tabular}

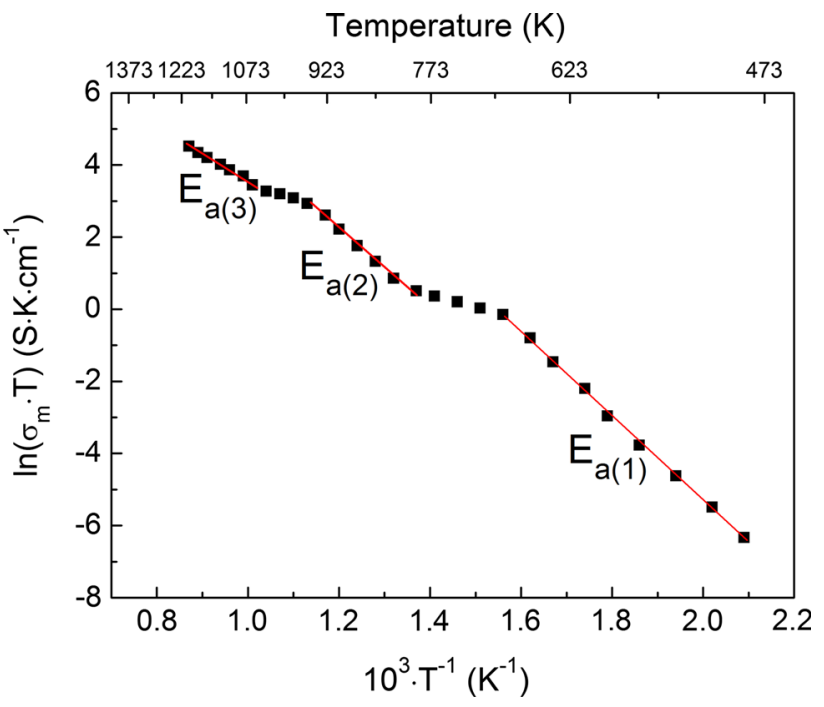

Fig. 9. Temperature dependence of electrical conductivity of the HEOX-30 h MS sinter after $10 \mathrm{~h}$ of sintering in air at $1273 \mathrm{~K}$ in an Arrhenius plot.

The conductivity of the HEOX-30 h MS sinter at $1148 \mathrm{~K}$ was equal to $8.03 \times 10^{-2} \mathrm{~S} \mathrm{~cm}^{-1}$. Moreover, a three-step course visible in the slope of the curves representing the dependence in question can be noticed in the studied range; this effect is related to phase transformation rather than a change in the mechanism that determines electrical conductivity. This is confirmed by the high-temperature x-ray investigations shown in Fig. 6.

Another possibility that might be taken into account is that heating the material during electrical conductivity measurements causes phase separation due to the low compatibility of $\mathrm{Zn}^{2+}$ and $\mathrm{Cu}^{2+}$ with other elements. The $\mathrm{Zn}^{2+}$ and $\mathrm{Cu}^{2+}$ are more prone to form non-rock salt phases- $\mathrm{Zn}^{2+}$ in the tetrahedral coordination (the most stable co-ordination state for $\mathrm{Zn}$ in the oxide form, see Table I) has an ionic radius that differs significantly from those of the remaining elements, while $\mathrm{Cu}^{2+}$ is affected by Jahn-Teller distortion. ${ }^{16,20}$ After electrical conductivity measurements had been completed and the sample was cooled to room temperature, a singlephase rock salt structure was observed; this phase had a lattice parameter of $4.23515( \pm 0.00011) \AA$.

The course of the conductivity vs. temperature dependence, which is linear in three temperature ranges, i.e. $478-641 \mathrm{~K}, 730-885 \mathrm{~K}$ and $990-1148 \mathrm{~K}$,
Table IV. Activation energy of electrical conduction $\left(E_{\mathrm{a}}\right)$ for the HEOX-30 h MS sinter

\begin{tabular}{|c|c|}
\hline Temperature range $(\mathbf{K})$ & $E_{\mathbf{a}}(\mathbf{e V})$ \\
\hline $478-641$ & $1.01 \pm 0.01$ \\
\hline $730-885$ & $0.91 \pm 0.03$ \\
\hline $990-1148$ & $0.62 \pm 0.03$ \\
\hline
\end{tabular}

suggests the activated character of electrical conductivity in the investigated sinter, in accordance with the following equation:

$$
\sigma_{m}=\frac{\sigma_{o}}{T} \exp \left(\frac{-E_{\mathrm{a}}}{k \cdot T}\right)
$$

where $\sigma_{m}$ is specific conductivity $\left(\mathrm{S} \mathrm{cm}^{-1}\right), \sigma_{o}$ is the pre-exponential factor, i.e. the material constant containing the carrier concentration term $\left(\mathrm{S} \mathrm{cm}^{-1} \mathrm{~K}\right), \mathrm{E}_{\mathrm{a}}$ is the activation energy of small polaron hopping $(\mathrm{eV}), k$ is the Boltzmann constant $\left(\mathrm{eV} \mathrm{K}^{-1}\right)$, and $T$ is absolute temperature $(\mathrm{K})$.

Based on the linear dependencies presented in Fig. 7, the activation energy of electrical conductivity of the investigated sinter was calculated using Eq. 3. The results obtained for the three specified temperature ranges are shown in Table IV.

The available literature data ${ }^{30-32}$ suggests that the small polaron mechanism which involves pairs of $\mathrm{Co}^{2+} / \mathrm{Co}^{\mathrm{III}}$ or $\mathrm{Cu}^{+} / \mathrm{Cu}^{2+}$ ions in the octahedral coordination may be responsible for conduction in the investigated sinter.

The contribution of iron contamination to electrical conductivity was ignored due to the negligibly low concentration of this element in studied sinter.

\section{CONCLUSIONS}

The mechanochemical synthesis (MS) technique was combined with the appropriate thermal treatment to obtain a fine, single-phase $(\mathrm{Co}, \mathrm{Cu}, \mathrm{Mg}$,$\mathrm{Ni}, \mathrm{Zn}) \mathrm{O}$ solid solution samples with the desired chemical and phase compositions. XRD examinations of the powders prepared via either $30 \mathrm{~h}$ or $100 \mathrm{~h}$ of MS indicated the presence of a mixture of two phases of rock salt structure and a phase of a $\mathrm{Co}_{3} \mathrm{O}_{4}$-based solid solution; the latter was found even after the MS time and BPR had been 
increased. After sintering the green bodies prepared from these powders for $10 \mathrm{~h}$ in air at $1273 \mathrm{~K}$, the $(\mathrm{Co}, \mathrm{Cu}, \mathrm{Mg}, \mathrm{Ni}, \mathrm{Zn}) \mathrm{O}$ high-entropy oxide in the form of a single-phase, solid solution with rock salt structure was obtained. SEM-EDS studies of the powders and sinters indicated the fine-crystalline structure of grains, with a uniform distribution of all elements. The porosity of the studied sinters did not exceed $12 \%$. The electrical conductivity of the studied sinter based on the powder obtained after $30 \mathrm{~h}$ of MS was measured by means of EIS, in the temperature range of $478-1148 \mathrm{~K}$ in air. The threestep course of the temperature dependence of electrical conductivity suggests that the studied sample exhibits behavior typical of a thermally activated process, and it is related to the phase reversal temperature. The highest activation energy, which was equal to $1.01 \mathrm{eV}$, was observed for the lowest temperature range $(478-641 \mathrm{~K})$, whereas the lowest value of $0.62 \mathrm{eV}$ was determined for the temperature range of 990-1148 K. The electrical conductivity of the $(\mathrm{Co}, \mathrm{Cu}, \mathrm{Mg}, \mathrm{Ni}, \mathrm{Zn}) \mathrm{O}$ high-entropy oxide at the highest temperature at which measurements were performed $(1148 \mathrm{~K})$ was equal to $8.03 \times 10^{-2} \mathrm{~S} \mathrm{~cm}^{-1}$.

\section{ACKNOWLEDGMENTS}

This work was performed as part of the statutory activities of the Department of Physical Chemistry and Modeling, Faculty of Materials Science and Ceramics, AGH University of Science and Technology (Contract No. 11.11.160. 768) and the Institute of Materials Science and Engineering, Faculty of Mechanical Engineering and Management, Poznan University of Technology (No. 02/24/DSPB/4657). The authors would also like to thank Professor Konrad Świerczek from the AGH-UST Faculty of Energy and Fuels for performing high-temperature XRD studies as well as Professor Mitsutoshi Ueda from the Tokyo Institute of Technology for the SEM-EDS analysis he performed.

\section{OPEN ACCESS}

This article is distributed under the terms of the Creative Commons Attribution 4.0 International License (http://creativecommons.org/licenses/by/4.0/), which permits unrestricted use, distribution, and reproduction in any medium, provided you give appropriate credit to the original author(s) and the source, provide a link to the Creative Commons license, and indicate if changes were made.

\section{REFERENCES}

1. B. Gludovatz, A. Hohenwarter, D. Catoor, E.H. Chang, E.P. George, and R.O. Ritchie, Science 345, 1153 (2014).

2. Y. Lu, Y. Dong, S. Guo, L. Jiang, H. Kang, T. Wang, B. Wen, Z. Wang, J. Jie, Z. Cao, H. Ruan, and T. Li, Sci. Rep. 4, 6200 (2014).

3. Y. Zhang, T.T. Zuo, Y.Q. Cheng, and P.K. Liaw, Sci. Rep. 3, 1455 (2013).
4. S.-K. Chen and Y.-F. Kao, AIP Adv. 2, 012111 (2012).

5. M.-H. Tsai, J.-W. Yeh, and J.-Y. Gan, Thin Solid Films 516, 5527 (2008).

6. P.-K. Huang, J.-W. Yeh, T.-T. Shun, and S.-K. Chen, Adv. Eng. Mater. 6, 74 (2004).

7. Y.-F. Kao, S.-K. Chen, J.-H. Sheu, J.-T. Lin, W.-E. Lin, J.-W. Yeh, S.-J. Lin, T.-H. Liou, and C.-W. Wang, Int. J. Hydrogen Energy 35, 9046 (2010).

8. A.D. Pogrebnjak, A.A. Bagdasaryan, I.V. Yakushchenko, and V.M. Beresnev, Russ. Chem. Rev. 83, 1027 (2014).

9. J. Gild, Y. Zhang, T. Harrington, S. Jiang, T. Hu, M.C. Quinn, W.M. Mellor, N. Zhou, K. Vecchio, and J. Luo, Sci. Rep. 6, 37946 (2016).

10. J. Zhou, J. Zhang, F. Zhang, B. Niu, L. Lei, and W. Wang, Ceram. Int. 44, 22014 (2018).

11. C.M. Rost, E. Sachet, T. Borman, A. Moballegh, E.C. Dickey, D. Hou, J.L. Jones, S. Curtarolo, and J.-P. Maria, Nat. Commun. 6, 8485 (2015).

12. D. Bérardan, S. Franger, D. Dragoe, A.K. Meena, and N. Dragoe, Phys. Status Solidi RRL 10, 328 (2016).

13. D. Bérardan, S. Franger, A.K. Meena, and N. Dragoe, J. Mater. Chem. A 4, 9536 (2016).

14. Z. Rak, C.M. Rost, M. Lim, P. Sarkar, C. Toher, J.-P. Maria, and D.W. Brenner, J. Appl. Phys. 120, 095105 (2016).

15. R. Djenadic, A. Sarkar, O. Clemens, C. Loho, M. Botros, V.S.K. Chakravanhanula, C. Kübel, S.S. Bhanttacharya, A.S. Gandhi, and H. Kahn, Mater. Res. Lett. 5, 102 (2017).

16. D. Bérardan, A.K. Meena, S. Franger, C. Herrero, and N. Dragoe, J. Alloys Compd. 704, 693 (2017).

17. C.M. Rost, Z. Rak, D.W. Brenner, and J.-P. Maria, J. Am. Ceram. Soc. 100, 2732 (2017).

18. S. Jiang, T. Hu, J. Gild, N. Zhou, J. Nie, M. Qin, T. Harrington, K. Vecchio, and J. Luo, Scr. Mater. 142, 116 (2018).

19. J. Dąbrowa, M. Stygar, A. Mikuła, A. Knapik, K. Mroczka, W. Tejchman, M. Danielewski, and M. Martin, Mater. Lett. 216, $32(2018)$.

20. A. Sarkar, R. Djenadic, N.J. Usharani, K.P. Sanghvi, V.S.K. Chakravadhanula, A.S. Gandhi, H. Hahn, and S.S. Bhattacharya, J. Eur. Ceram. Soc. 37, 747 (2017).

21. C. Pathak, D. Mishra, V. Agarwala, and M. Mandal, Ceram. Int. 38, 6191 (2012).

22. Y.X. Li, W.F. Chen, X.Z. Zhou, Z.Y. Gu, and C.M. Chen, Mater. Lett. 59, 48 (2005).

23. J. Lu, K.M. Ng, and S. Yang, Ind. Eng. Chem. Res. 47, 1095 (2008).

24. M. Seyedia, S. Haratiana, and J. Vahdati Khakia, Procedia Mater Sci 11, 309 (2015).

25. R.D. Shannon, Acta Crystallogr. A 32, 751 (1976).

26. Y.-M. Chiang, D.P. Birnie, and W.D. Kingery, Physical Ceramics: Principles for Ceramic Science and Engineering (Hoboken: Wiley, 1997), pp. 15-16.

27. S. Chevalier, G. Caboche, K. Przybylski, and T. Brylewski, J. Appl. Electrochem. 39, 529 (2009)

28. H.M. O'Bryan and G. Parravano, Reactivity of Solids (Amsterdam: Elsevier Publishing Co., 1965), p. 256.

29. C.E. Lyman, D.E. Newbury, J. Goldstein, D.B. Williams, A.D. Romig Jr, J. Armstrong, P. Echlin, C. Fiori, D.C. Joy, E. Lifshin, and K.-R. Peters, Scanning Electron Microscopy, $X$ Ray Microanalysis, and Analytical Electron Microscopy: A Laboratory Workbook (Berlin: Springer Science \& Business Media, 2012), p. 407.

30. H. Bordeneuve, C. Tenailleau, S. Guillemet-Fritsch, R Smith, E. Suard, and A. Rousset, Solid State Sci. 12, 379 (2010)

31. B. Talic, Metallic Interconnects for Solid Oxide Fuel Cells: High Temperature Corrosion and Protective Spinel Coatings. Ph.D. thesis, Publisher NTNU, Series Doctoral thesis at NTNU;2016:221 (2016).

32. E.J.W. Verwey, Semiconducting Materials (London: Butterworths Scientific Publications, 1951)

Publisher's Note Springer Nature remains neutral with regard to jurisdictional claims in published maps and institutional affiliations. 